\title{
AGING IN RURAL AREAS IN AUSTRIA - ON THE INTERRELATIONS OF SPATIAL ASPECTS AND THE QUALITY OF LIFE OF TODAY'S OLDER GENERATION
}

\author{
Tatjana Fischer ${ }^{1}$
}

Received 11 September 2008; Accepted 22 June 2009

\begin{abstract}
The impact of demographic change and the increasing polarization into structurally strong and weak rural areas lead to new challenges for today's older generation in rural area in Austria in terms of growing old in a self-determined way: The quality of the activities of daily life is strongly affected by spatial aspects. Aside from factors related to natural environment above all factors related to the spatial structure are of great importance, such as the supply of infrastructure. This results in large differences in the quality of growing old in differently structured rural areas. Spatially relevant aspects manifest themselves to varying extents depending on the requirements of different groups of elderly people: While those who are still healthy, those who have a driving-licence and a stable economic background are hardly affected by spatial aspects, deficiencies in the supply of services primarily have an impact on those who are physically handicapped, not integrated into any social networks, who have little money and on those involved in securing the quality of life of the elderly such as family members and employees in mobile services of (social) medical care of the elderly. This article bases upon my doctoral thesis "Aging in rural areas - a spatial analysis" finished in 2005. It comprises the contents of the latest literature (2005) and the results of a solid field research in four rural Austrian microregions. The following statements are related to these micro-regions.
\end{abstract}

Key words: Today's older generation - demographic change - quality of life - supply of infrastructure - rural areas

Zusammenfassung: Die Auswirkungen des demographischen Wandels und die zunehmende Polarisierung in strukturstarke und strukturschwache ländliche Räume führen zu neuen Herausforderungen in Hinblick auf die Möglichkeit eines selbst bestimmten Älterwerdens im ländlichen Raum: Die Qualität der Aktivitäten des täglichen Lebens wird sowohl in quantitativer als auch in qualitativer Hinsicht von räumlichen Aspekten beeinflusst, wobei neben naturräumlichen Faktoren vor allem raumstrukturellen Merkmalen wie etwa der Ausstattungsgrad mit Infrastruktur große Bedeutung zukommt. Die Qualität des Altwerdens im ländlichen Raum weist demnach große Unterschiede zwischen verschieden strukturierten ländlichen Raumtypen auf. Raumrelevante Aspekte manifestieren sich je nach Anspruchsgruppe bereits heute in sehr unterschiedlichem Ausmaß: Während sie die Lebensqualität rüstiger,

\footnotetext{
${ }^{1}$ FISCHER Tatjana, Institute of Spatial Planning and Rural Development, Department of Spatial, Landscape and Infrastructure Sciences, University of Natural Resources and Applied Life Sciences, Vienna, Peter Jordan Straße 82, A-1190 Wien, Österreich, e-mail: fischer@boku.ac.at
} 
automobile älterer Menschen kaum beeinflussen, zeigen sich beispielsweise Versorgungsdefizite des Wohnumfelds in Auswirkungen auf die Lebensqualität nichtautomobiler älterer Menschen, hilfs- und pflegebedürftiger und finanziell schlecht gestellter älterer Menschen sowie in den wachsenden Anforderungen an die an der Sicherung der Lebensqualität älterer Menschen mitwirkenden Anspruchsgruppen wie pflegende Angehörige und Beschäftigte in der mobilen Betreuung. Es ist wichtig zu verstehen, dass hinter der Lebensqualität älterer Menschen komplexe UrsachenWirkungs-Gefüge hinsichtlich räumlicher Aspekte stehen. Diese werden in dieser Arbeit anhand von vier unterschiedlich strukturierten ländlichen Kleinregionen Österreichs aufgezeigt und analysiert sowie bereits vorhandene Lösungsansätze zur Sicherung der Lebensqualität der älteren Menschen im ländlichen Raum vorgestellt. Inhaltlich abgerundet wird diese Arbeit durch einen Ausblick in die nähere Zukunft unter Berücksichtigung sich bereits heute abzeichnender raumrelevanter Trends. Um auch in Zukunft die Lebensqualität aller im ländlichen Raum lebenden älteren Menschen erhalten zu können, ist es erforderlich, die Treffsicherheit von Lösungsansätzen durch die Berücksichtigung raumrelevanter Aspekte zu erhöhen

Schlüsselwörter: Ältere Menschen / Demographischer Wandel / Lebensqualität / Ländlicher Raum / Ländliche Entwicklung

\section{Problem definition}

This paper analyses the spatial aspects concerning the quality of life of today's older generation in differently structured rural areas in Austria. Socio-demographic as well as socioeconomic developments cause increasing polarisation into structural strong and structural weak regions. That's why functional structures break up and new challenges emerge considering the opportunities of a self-determined aging in rural areas. The results are taken from the doctoral thesis "Aging in rural areas - a spatial analysis".

\section{Methodology}

The complexity of the question demands a combination of spatial and sociological aspects. The aim is to register the status quo of the quality of life of today's older generation in detail. The best way how to get reliable results is to apply qualitative and quantitative methods of empiric social research, particularly methods of field research. It is very important to dive into the "rural world" and experience it from the point of view of old people.

\section{Excursus: About the organisation and performance of the field research}

The selection of the four micro-regions - based upon considerations relating to geographic aspects, demographic developments (analysis of statistical data) and terms of infrastructure was followed by a profound field research in these rural areas.

First of all the mayors have been informed about the aim of the field work in their municipalities. They were asked to describe their own municipality to allow a look at the moods of today's older generation and the circumstances of their everyday's life. The mayors also named relevant contact persons like e.g. employees in mobile services of ambulant (social) medical care of the elderly, chairpersons of political senior associations, furthermore addresses of people older than 60 years. A long phase of field research consisting of doing interviews with more than 100 people and inspecting the municipalities by foot began.

One of the most impressive experiences for me was the opportunity to accompany the employees in mobiles services.

Reviewing the methods applied I have to say that the drawing of the sample was not systematic. That is why at the beginning of the field research the mayors as "door openers" to the municipal population caused a kind of selection of potential contact persons for the questionnaire.

At this point I want to emphasize that the aim of the doctoral thesis does not claim representative results for today's older generation in rural areas in Austria as a whole, but to 
help to understand the interrelations of spatial aspects - that differ much from rural area to rural - and the quality of life of the rural $60+$ on principle.

\subsection{A short description oft the four selected rural micro-regions}

There is a great variety of rural areas. That implies the necessity of selection: Showing the interrelations of spatial aspects and the quality of life of today's older generation, four differently structured rural micro-regions have been chosen:

"Thaya-March-Grenzland" is a peripheral micro-region situated near the former Iron Curtain in Lower Austria and comprises four municipalities. It is characterized by a continuous loss of primary dwellers and an increasing number of secondary dwellers. It belongs to the so-called "structurally weak" micro-regions.

"Südwestliches Eisenstädter Umland" is a structurally strong region next to the capital of Burgenland. The six municipalities are functionally interlaced with the capital Eisenstadt. This micro-region continuously gains both primary as well as secondary dwellers.

The peripheral inner-alpine micro-region "Inneres Salzkammergut" is situated in the south of the Upper Austrian district Gmunden. Tourism plays an important economic role. Each of the four municipalities has high rates of secondary dwellers. Migration of primary dwellers leads to a decreasing number of inhabitants (primary dwellers) and aging.

The "Mürzer Oberland" is an inner-alpine peripheral micro-region in Styria. The structurally weakness of this old industrial region (district Mürzzuschlag) implies from the socioeconomic decline during the past thirty years. The four municipalities all suffer from aging, selective migration. On the one hand they lose primary dwellers on the other hand the number of secondary dwellers is increasing.

\subsection{Working definition "Today's older generation"}

The target population group are persons aged over 60 who still live at home with our without external help. Old people living in stationary institutions like nursery homes are not taken into account because their everyday's lives are not affected by spatial aspects anymore. Secondary dwellers and old people with migration background are unconsidered. Mentally handicapped old people (dementia) are also excluded from the study because the author lacks medical and psychological knowledge.

The profile of today's older generation in rural areas can be described as the following:

- wide range of age (30 years),

- heterogeneity regarding the former employment (farmers, workers, employees, commuters),

- heterogeneity regarding the lifestyles and demands,

- Most of them have spent their whole lives in their home municipalities.

This aspects lead to differentiation within the group of the old people regarding the

- state of health

- financial situation

- structural and technical qualities of the dwellings

- quality of social networks and support

- (auto) mobility

These attributes differ from rural area to rural area.

Similarities among today's older generation in rural areas are:

1. Structured day: Zohner $(2000,59$ f.) is confirmed when he emphasizes the importance of a structured day in everyday's life of today's older generation: Forenoon the old people do their house holds and the shopping, the afternoon is free and available. The old often spend their evenings at home. 
2. Small number of today's older generation owns a driving-licence: Only one third of the over 65 year old people in municipalities up to 5000 primary dwellers own a driving-licence (compare Sammer et al. 2000, 40).

3. Importance of the dwelling and the residential environment: The own house and/ort he own dwelling is a place of silence and recreation. Most of the spare team is spent at home. That is why public space in all of the four micro-regions seems to be deserted at the weekend. In Amann's opinion (Amann, 2000) in the future the importance of one's dwelling will become more relevant for the old.

4. Similarities relating to leisure activities: Television plays an important role in every day's life of old people. The structure of the day and the planning of (outdoor) activities often depend on the "television programme".

Most of the interviewed old people who are not auto-mobile confirm that their activities are restricted to the near residential environment. (Political senior) associations are of major relevance for the social life of today's older generation. Going in for sports is among the leisure activities of the healthy, vigorous old people. Hiking plays an important role in "Inneres Salzkammergut", "Mürzer Oberland" and partly in "Südwestliches Eisenstädter Umland".

\subsection{Working definition "Quality of life"}

There are many approaches regarding the measurement of quality of life. Within the doctoral thesis the complexity of this term has been defined as the following:

5. Objective components of quality of life of today's older generation: These components comprise

- Daily supply with goods and services: e.g. food, cosmetics, medicine, news papers; postal and bank services, personal services like hair dressers, pedicurists

- Ambulant and stationary (social) medical care: doctors; nursery, hospitals, nursing homes; hospices, terminal care at home

- Quality of social networks: integration of the old into their families and village community; communication and support between the old themselves, the relevance of political senior and other associations, the relevance of the Church and further meeting points.

6. Subjective components of quality of life of today's older generation

Depending on one's position in the life cycle there are three emphasized aspects:

- living a self-determined life at home

- keeping up one's (auto-)mobility as long as possible

- opportunity to depart this life at home

\section{The relevance of spatially relevant aspects for the quality of life of today's older generation in rural areas}

Illustrating the interrelations of spatial aspects and the quality of life of today's older generation in rural areas it has to be stated that spatial aspects come into one's mind when one's growing old, mobility is shrinking and spatial vicinity gains relevance.

Aging is being discussed broadly within science and politics. One of the results is that thinking about aging and its consequences for one's own life first often starts when problems arise. The background of the worsening of the quality of life often is related to spatial aspects. In turn spatial are being perceived very differently.

In the general spatially related aspects can be clustered as the following:

- Natural environment

- Spatial aspects relating to the structures of settlements

- Socio-spatial aspects 


\subsection{Natural environment}

Climatic factors like raw climate (low temperature, wind, rain, wetness, fog) affect themselves on the health of old people. According to the interviewed persons in the inner-alpine regions these factors cause a frequent occurrence of cold diseases and strengthen existing chronic diseases, rheumatism for instance.

Lighting conditions (hours of sunshine, daylight) are being blamed for (seasonal affective) depressions ("Inneres Salzkammergut", "Mürzer Oberland").

In inner-alpine regions snow and glazed frost complicate accessibility in winter. This not only causes problems for the old themselves but also particularly for employees in mobile services (e. g. nurses). They often have to put on snow chains because the streets often are steep and icy. Worst case the employees can't reach their clients by car and have to put on skis. Shovelling show is part of their work, too.

Natural hazards like avalanches or floods often cut off villages of world outside. In this case employees within ambulant (social) medical care depend on the support of other rescue services (mountain rescue for instance, "Inneres Salzkammergut") getting to their clients.

Topographic factors determine substantially the economic structural strength of a municipality and/or the micro-regions, because the different employment structures appear in different numbers of commuters as well as in selective migration. In turn that affects the local facilities and utilities and supply structures as well as the quality of social networks.

Structural conditions of residential areas like stretched valleys ("Mürzer Oberland") cause long distances between villages. That implies big efforts: large driving expenditure for mobile personnel and the old. The latter often have to visit the next (regional) centres because the local structures of daily supply often don't meet the requirements (number of shops, quality of products, height of prices).

Exposition of residential areas: Inner-alpine areas often are characterized by small settlement areas as well as disperse settlement structures and extreme slope inclinations. Many persons of today's older generation live in their old (farmer) houses. Those who don't have any driving licence or who are not allowed to drive any longer have serious problems to get to the local centre of the village. In turn the mobile nursing-staff for instance has to accept long travelling times.

\subsection{Spatial aspects relating to the structures of settlements}

The size of the municipalities and their administrative organisation (cadastral municipalities) indicate different structures of supply facilities. A high number of cadastral municipalities within a sparsely populated residential area lead to an undersupply of those old non-automobile people who live outside the village centre. Low population densities in cadastral municipalities are a disadvantage, too, because they influence effective demand and use of e.g. public transport (busses).

Settlement structures influence the development of municipalities and the establishment of institutions and shops there. This helps to explain the problems relating to accessibility of nonautomobile old people who live in stretched ribbon-built villages (long ways - long distances). This kind of villages often lacks a defined village centre with a concentration of institutions and shops. This problem specifically exists in scattered settlements: The long distances between the dwellings (houses) of the old determine the frequency of visiting each other (non-automobile persons). On the contrary clustered villages tend to shorter distances and often have a defined village centre with concentration of institutions and shops. Clustered villages can be developed easier that's why their local facilities and utilities are better in comparison to scattered settlements.

Settlement development: Settlements often develop outwards. This causes housing sprawl. Stretched ribbon-built villages ("Südwestliches Eisenstädter Umland", "Thaya-MarchGrenzland") often are affected. That implies disperse settlement structures, long distances between the houses and the village centre and burdens the financial budget of the 
municipalities (developing costs). Housing sprawl has also led to collective aging of several parts of residential areas

The quality of public space regarding the footpaths, pavements and cycle tracks: None of the four micro-regions offers a continuous net regarding the footpaths or cycle tracks. This would be very necessary because many old people are using bikes for their daily ways and shopping (village centres). Footpaths often lack shielding from motorised individual transport, structural boundaries are missing. In scattered settlements people often have to walk on road flanks. The lighting often is inadequate ("Inneres Salzkammergut", "Mürzer Oberland").

Meeting points outdoors: Nearly all of the municipalities of the four micro-regions are equipped with benches. They invite to rest and sit down and talk a bit with other people of the village. In the past, benches played an important role in social gathering.

Quality of local facilities and utilities (variety of institutions and shops): This aspect is very meaningful because the quality of daily supply with goods and services in the village centres themselves (local level) is very important for those among the old who depend on immediate vicinity. Low qualities and high prices of goods affect the non-automobiles unless they can evade this problem when their relatives, friends or neighbours give them a lift. Hair dressers and pedicurists often offer mobile services.

Availability and quality of public transport:

Number and position of bus stops and railway stations: Railway stations often are sited outside the village centres, at the edges of the municipalities. Most of the old people get to the railway stations by bike or by car. The bus stops often are scattered over the residential areas and mostly are sited at strategic points like (former) postal offices, (former) elementary schools, municipal office or restaurants and/or inns. Municipalities consisting of many cadastral municipalities often have bus stops in those cadastral municipalities with sufficient population densities.

Equipment of bus stops: Bus stops only are often marked by simple signboards and benches. Bus shelters often are uncomfortable. At highly frequented (main) roads ("Inneres Salzkammergut") waiting for the bus is uneasy at the evening because for example a good lighting system is often missing.

Quality of public transport facilities: In rural areas public transport often is solely used by people who are not auto-mobile (during the week) like old people, children, young people and (young) mothers. If there is a doctor's appointments in the next regional centre or hospital-visits to do they have to use public transport.

The density of intervals depends on the daytime as well as on schooldays and vacations, weekdays and holidays. That implies a big variation of effective demand and very complicated schedules ("Mürzer Oberland"). One has to be at the bus stop on time, changing busses is laboriously, one often has a long wait when having missed a bus. These circumstances are physically exhausting and need lots of time and are often termed "one-day trips" ("Mürzer Oberland").

Dwelling and residential environment: The one-family house still dominates the rural areas in Austria. Today's older generation often lives in old structures that are not barrier-free: Both bathroom and sleeping room are on the first floor; bathrooms and toilets often are too small. Ascending a staircase becomes a problem when old people are physically handicapped. That is why there often occur problems for mobile nurses handling their job.

Technical equipment of the private households: Many of the old (farm) houses are still being heated by wood and coal. Along with that running hot-water has not come up to a standard yet ("Inneres Salzkammergut"). Many of the private households of old people lack facilities like microwave oven, gas or electric stove. This makes cooking and preparing the refrigerated menus of "meals on wheels" is very difficult.

The size of the dwellings (farmhouses) and their surrounding gardens are of importance when old (widowed) people are forced keeping the household alone. For many of them this is very exhausting that is why they make use of specific mobile services or get support from their relatives, particularly from their children. 


\subsection{Socio-spatial aspects}

The availability and quality of social networks not only differ from micro-region to micro-region. There are also differences between the municipalities of a micro-region and within a municipality. In municipalities where agriculture still is an important employer it can be assumed that the elderly are cared for at home within the family. The living-together of the generations still exists, but there are differences between the four micro-regions: Regarding this especially in peripheral rural areas the continuous trend of selective migration, personal reasons and financial aspects (costs for rebuilding the old houses) lead to decreasing.

The integration of today's older generation into the village community closely depends on the health situation and growing old. In case of need of care the affected persons can't leave their homes any more. The personal contacts to others are mostly kept up by chairpersons and subcashiers of (political senior) associations who visit their members at home. The social cohesion between "the young and the old" mostly is confined to the own family. In most cases old people depend on the support of other old people because most of the employed persons are commuters and not present during the day. The phenomenon of collective aging of whole settlements occurs in all micro-regions and leads to segregation of age-groups within the municipalities. Collective aging also reduces the opportunities to aid one another.

Support from outside the family (friends, neighbours) strongly depends on "one's past in the municipality". Former commuters have more problems because they have to re-build their social networks and they mostly have left their friends at the former working places (in regional centres, capitals). Those who were "secondary dwellers against one's will" but took part in the village community (being involved in various associations) don't have many problems to reintegrate.

Political senior associations, other associations and the Church play an important role in the lives of today's older generation. Most of them prefer coming together organized, the younger ones among the age-group over 60 exclusively like private meetings. Today's older generation are the main girders of social life in the municipalities because they are permanently present. Surprisingly the motivation for active collaboration within the associations and the taking of honorary posts or functions is quite low. This can be shown in all four micro-regions.

\section{The interrelations of spatial aspects and the quality of supply}

The following three figures show - basing upon the analysis of statistical data and the field research in the four micro-regions - three examples of impacts of spatial aspects on the structure of daily supply of goods, on mobile services of (social) medical care of the elderly as well as on the quality of social networks and point out how deficiencies come into being because of spatial aspects. 


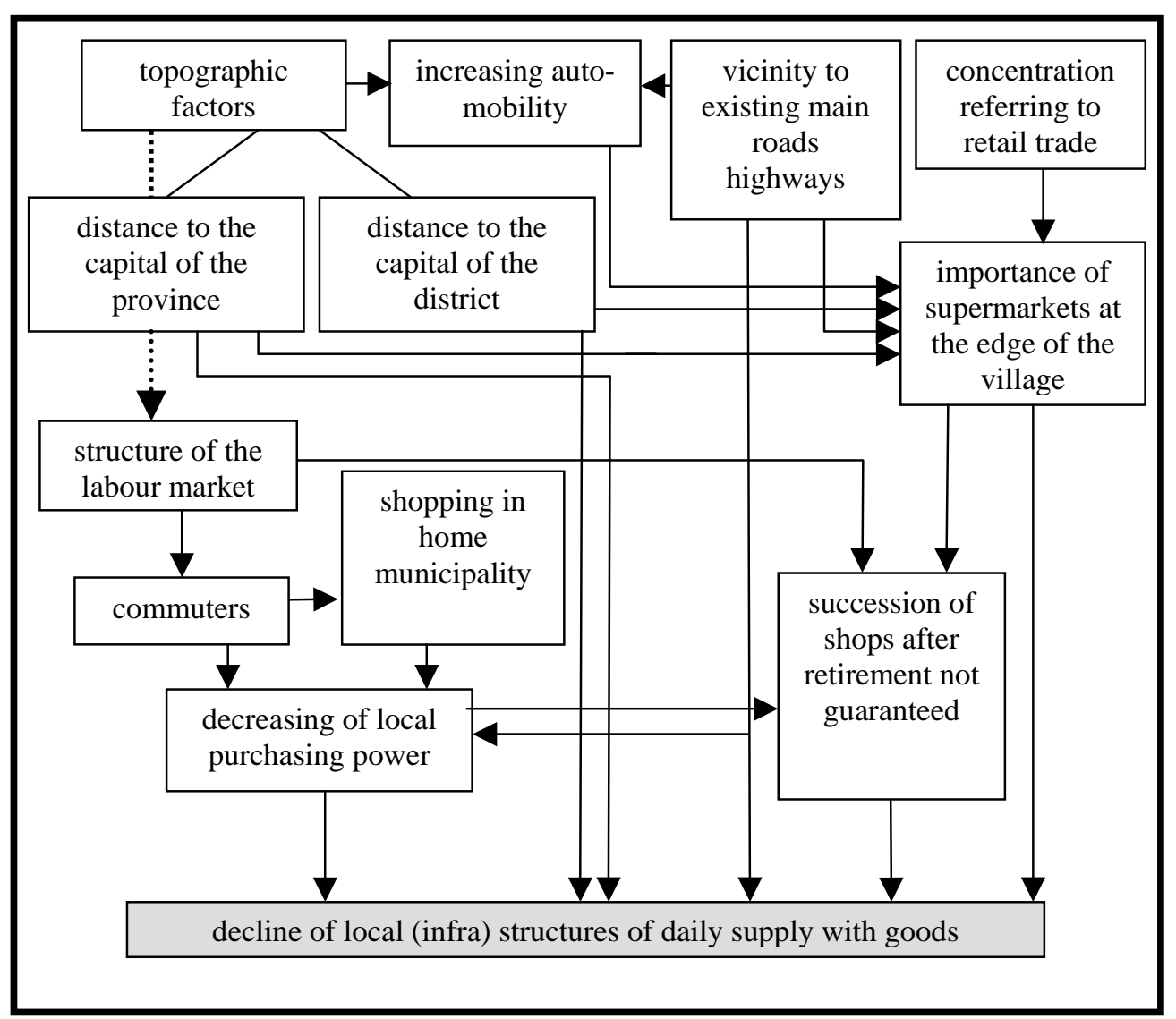

Fig 1. Spatial aspects and daily supply (compare Fischer (2005, 150), adapted by Fischer)

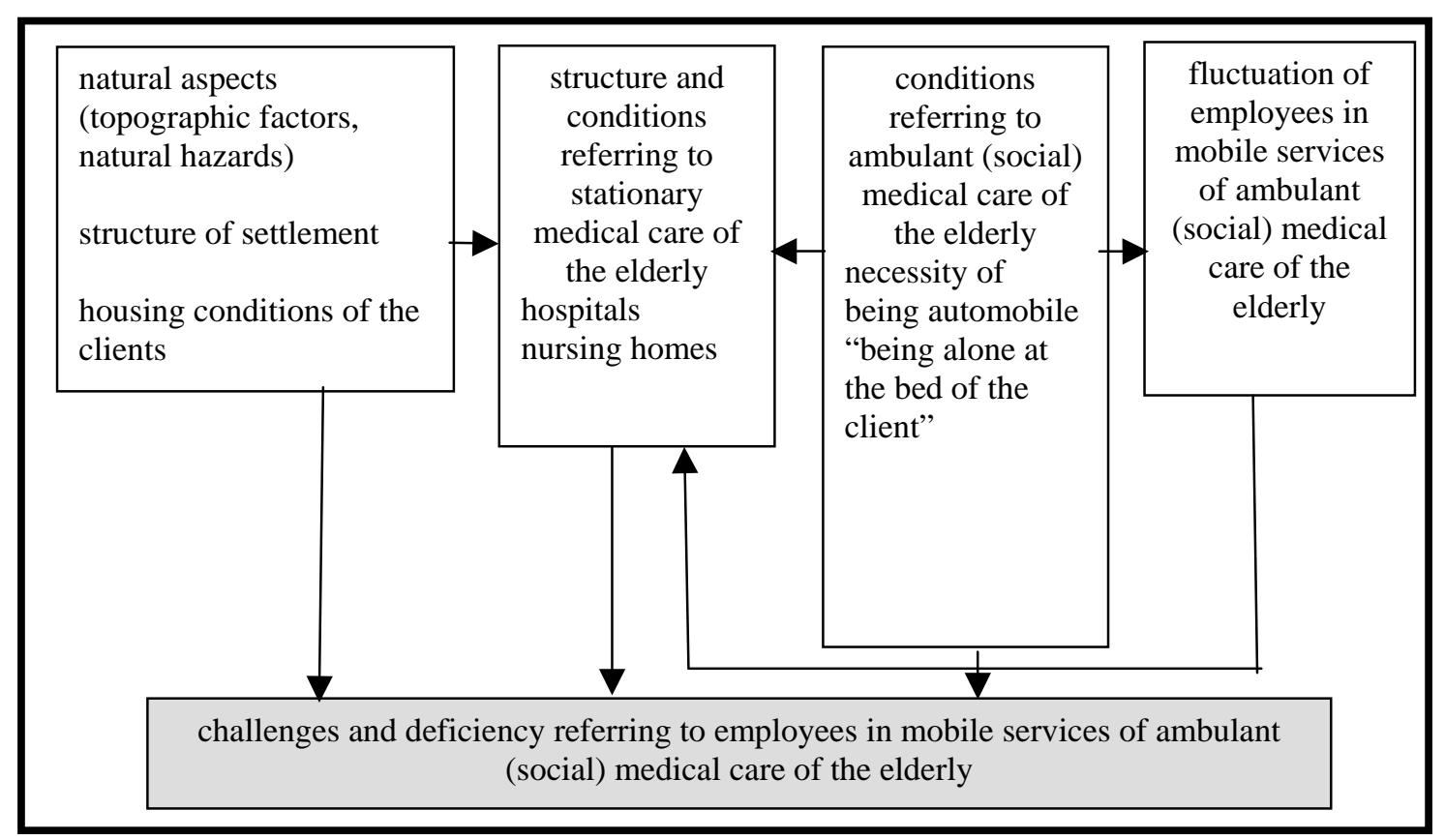

Fig 2. Spatial aspects and mobile services of (social) medical care of the elderly (compare Fischer (2005, 147), adapted by Fischer) 


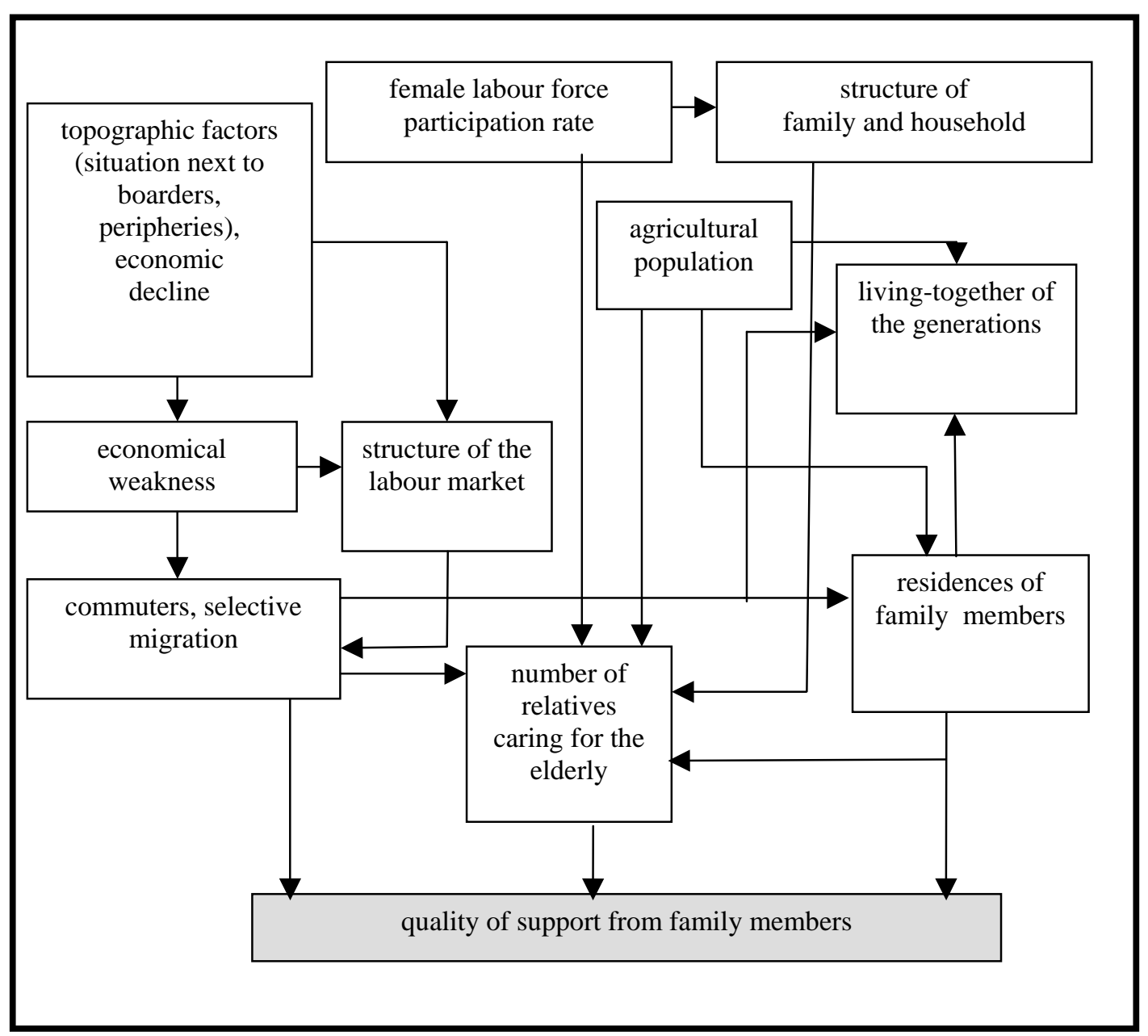

Fig 3. Spatial aspect and social networks (compare Fischer (2005, 148), adapted by Fischer)

\section{The impacts of spatial aspects on the quality of supply of today's older generation depend on the structure of rural areas}

In all four micro-regions the daily supply with goods and partly with services still exists at the local level. But there is an orientation to regional centres. In the suburban "Südwestliches Eisenstädter Umland" the old do their shopping in the provincial capital Eisenstadt, in the "Inneres Salzkammergut" the old leave the micro-region for their activities and go to Bad Ischl. The reason for the increasing of that "outward orientation" lies in better offers, the quality of shops, the level of prices and the quality of goods.

The quality of (social) medical care of the elderly differs from micro-region to micro-region. There are differences relating to the offered mobile services, organisational structures (e. g. meals on wheels) as well as to the facility of terminal care at home. Economically strength and development of primary dwellers in a region depend on one another and imply the service portfolio and quality of mobile services of (social) medical care of the elderly. That is why these both factors determine the continuity of demand of mobile services and stationary medical care of the elderly.

Spatial aspects also affect the quality of social networks of today's older generation: In structurally weak rural areas selective migration of young people causes reduced family support. In agrarian structured rural areas the living-together of generations has a long tradition and is still alive in many places. Low female labour force participation rates contribute to better integration of the old who are in the need of help in their families. The potential of family support exists in suburban rural areas, too, because the employed relatives who often are daily commuters often live in the same and/or the neighboured municipality. The quality of help offered from neighbourhood strongly depends on "the common past in the village" and the structure of personality of the old. The rejuvenation of age, the plurality of lifestyles as well as 
the increasing of individuality induce changes regarding the importance of any associations (e. g. political senior associations) and the importance of the Church in social every day's life of the old. Informal, new organized networks emerge. Referring to the statements of the interviewed persons it can be assumed that the quality of life of the non-automobile old people is endangered, particularly in structurally weak rural areas. It is very interesting that the old often do not realize deficiencies of their residential environment, because they make them up emphasizing the benefits like "silence, fresh air, sound nature and the mountains".

One important conclusion driven from the results above is that while in structurally weak rural areas people fear the decreasing of daily supply (goods and services) and (social) medical care at the local level, further diversification of supply in all intents and purposes in structurally strong rural areas is welcome.

\section{Saving the quality of life of today's older generation in rural areas in Austria - existing approaches to solution}

Looking at the existing approaches to solution for enabling and saving the quality of life of the whole - and not only today's older - rural population makes evident that each approach tries to compensate spatial deficiencies, especially the loss of spatial and social vicinity.

Particularly guaranteeing aging in rural areas at a high level the provinces and municipalities (in the selected micro-regions) already have created and implemented various more or less successful approaches:

Relating to daily supply with goods and services the measures cover consciousness-raising that focus at changing one's buying-behaviour and saving local infrastructure ("Inneres Salzkammergut"), house delivery and mobile merchants ("Mürzer Oberland"). The latter are being thought of as "second choice". New mobile services (mobile hair dressers, masseurs) will be well accepted ("Inneres Salzkammergut").

Relating to (social) medical care of the elderly home visits and medicine chests of the doctors are most important. These measures are of value for those who are physically handicapped and/or non-automobile and living in scattered settlements. Organisational measures relate to the reduction of the length of ways and travel times of employees of mobile services of (social) medical care. That is why tour planning is reconciled at the residential area of the employees. If providers of mobile (social) medical care of the elderly identify changes relating to demand they try to react quickly and to force specific segments of mobile offers.

Organised help from the neighbourhood plays an important role relating solutions regarding social networks ("Inneres Salzkammergut"). The aim is to create small-scaled spatial support systems that take the pressure off family members and employees in mobile services of (social) medical care of the elderly. Organised help from the neighbourhood is marked by voluntariness, freedom of charge as well as by spatial and personal vicinity between those who offer help and those who accept help. (Political) senior associations are very important for today's older generation, because they offer lots of (organised) leisure activities (sporting, journeys) for those who are still young and healthy. (Political) senior associations with few (active) members try to focus on the needs of "their old people" who often have little money and other needs (e. g. necessity of "pastoral" care). There are some good examples for well-performing small associations in "Inneres Salzkammergut" and in "Mürzer Oberland" that cover "pastoral care" above all.

Many of those good practices relating to social networks depend on the commitments of the municipalities and on the efforts of the various associations. As a result multi-functional use of infrastructure (e. g. rooms in elementary schools and/or parish houses) is enabled.

From the spatial planner's point of view it is very important not only to cure the symptoms of spatial development and trends, but also to zero in on prospective approaches that offer sustainable solutions for the future coping with the reasons for deficiencies.

The primary objectives are stabilising the population (primary dwellers) and coping with the thinning of social networks (particularly family support). A good example for a prospective 
approach is the extension of child care in one of the suburban municipalities of "Eisenstädter Umland".

\section{Spatial trends in rural areas}

The majority of rural areas in Austria suffer from the consequences of spatial trends being described in the following: The shrinkage of population (resp. primary dwellers) in structurally weak rural areas, the polarization into structurally weak and strong rural areas relating to (socio) economic development, the increasing auto- mobility (of the old), the changing buying behaviour as well as spatial and settlement development imply long ways and thinning of infrastructure of daily supply at the local level and the rising of the demanders for all kinds of mobile services (compare figure 4).

It can be assumed that the heterogeneity of the profiles of the old will increase: Today's older generation cannot be equated with agrarian population. In the near future there will be changes relating to requirements and demands of tomorrow's older generation because the rural and urban systems of values assimilate.

\section{References}

[1] Amann, A. (2000). Umwelt, Mobilität und Kompetenzen im Alter. In Zentrum für Alternswissenschaften und Sozialpolitikforschung (ZENTAS). St. Pölten: Schriftenreihe der NÖ Landesakademie, Band 21/Teil I.

[2] Fischer, T. (2005). Aging in rural areas - a spatial analysis. Unpublished doctoral thesis, University of Natural Resources and Applied Life Sciences, Vienna.

[3] Sammer et al. (2000). MOVE - Mobilitäts- und Versorgungserfordernisse im strukturschwachen ländlichen Raum als Folge des Strukturwandels. 1. Zwischenbericht, Wien: Universität für Bodenkultur Wien.

[4] Zohner, U. (2000). Die Lebenssituation älterer Menschen und ihr Verhalten als Besucher von Seniorenkreisen. Eine sozialgeographische Untersuchung in Braunschweig und Peine. Unpublished dissertation. Georg-August-Universität zu Göttingen. 